\title{
STRATEGI PEMASARAN BERAS ORGANIK DI GAPOKTAN SIMPATIK TASIKMALAYA
}

\author{
Organic Rice Marketing Strategy In Gapoktan Simpatik Tasikmalaya \\ Ade Resha Nova Dwiastuty*) \\ Agriani Hermita Sadeli \\ Sri Fatimah \\ Nur Syamsiyah
}

Fakultas Pertanian Universitas Padjajaran, Jawa Barat, Indonesia

Email: ade16010@mail.unpad.ac.id ${ }^{*}$

\begin{abstract}
The need for organic rice every year always increases by 5\%. This is due to changes in people's lifestyles that begin to pay attention to healthy lifestyles. It becomes an opportunity for entrepreneur or farmers to develop organic rice business. One of the farmer groups that develop organic rice business is Gapoktan Simpatik. The market share of Gapoktan Simpatik organic rice includes local and international markets. But since 2014, organic rice sales in Gapoktan Simpatik have tended to decline. This is due to increased competition in the organic rice business in the global market. Therefore, efforts to increase sales of organic rice need to be formulated marketing strategies. The purpose of this study is to obtain an alternative strategy that can be implemented by Gapoktan Simpatik in solving these problems so that the development of the Gapoktan Simpatik organic rice business can run well and optimal. The marketing strategy formulation in this research was carried out through an analysis of the company's environment using IE and QSPM matrix calculations. The analysis shows that there is a high level of competition which is a threat to Gapoktan Simpatik in developing the organic rice business, causing a lack of market share for Gapoktan Simpatik. An alternative strategy that must be carried out by Gapoktan Simpatik is to increase cooperation with various relevant partners.
\end{abstract}

Keywords: Marketing Strategy, Organic Rice, QSPM (Quantitative Strategic Planning Matrix)

\begin{abstract}
ABSTRAK
Kebutuhan akan beras organik setiap tahunnya selalu mengalami peningkatan sebesar 5\%. Hal ini disebabkan karena adanya perubahan gaya hidup masyarakat yang mulai memperhatikan pola hidup sehat. Sehingga hal tersebut menjadi peluang bagi pelaku usaha atau kelompok tani untuk mengembangkan bisnis beras organik. Salah satu pelaku usaha atau kelompok tani yang mengembangkan bisnis beras organik yaitu Gapoktan Simpatik. Pangsa pasar beras organik Gapoktan Simpatik mencakup pasar lokal dan internasional. Tetapi semenjak tahun 2014, penjualan beras organik di Gapoktan Simpatik cenderung mengalami penurunan. Hal ini disebabkan karena meningkatnya persaingan bisnis beras organik di pasar global. Oleh karena itu, upaya untuk meningkatkan kembali penjualan beras organik perlu
\end{abstract}


dilakukan perumusan strategi pemasaran. Tujuan penelitian ini untuk mendapatkan alternatif strategi yang dapat dilaksanakan oleh Gapoktan Simpatik dalam memecahkan masalah tersebut agar pengembangan bisnis beras organik Gapoktan Simpatik dapat berjalan dengan baik dan optimal. Perumusan strategi pemasaran dalam penelitian ini dilakukan dengan melalui analisis lingkungan perusahaan dengan menggunakan perhitungan matriks IE dan QSPM. Hasil analisis menunjukkan bahwa adanya tingkat persaingan tinggi yang menjadi ancaman bagi Gapoktan Simpatik dalam mengembangkan bisnis beras organik sehingga menyebabkan kurangnya pangsa pasar bagi Gapoktan Simpatik. Alternatif strategi yang harus dilakukan oleh Gapoktan Simpatik yaitu meningkatkan kerjasama dengan berbagai mitra yang terkait.

Kata Kunci : Strategi Pemasaran, Beras Organik, QSPM (Quantitative Strategic Planning Matriks)

\section{PENDAHULUAN}

Sektor pertanian merupakan sektor yang memiliki peranan penting dalam pembangunan nasional, bahkan sampai sekarang sektor pertanian memegang peranan strategis dalam struktur pembangunan perekonomian nasional (Sri, 2017). Sektor pertanian terdiri dari beberapa subsektor, diantaranya yaitu subsektor pangan. Pangan merupakan kebutuhan pokok yang sangat penting bagi kehidupan bangsa. Oleh karena itu, kebutuhan pangan perlu diupayakan ketersediannya dalam jumlah yang cukup, kualitas yang bagus, dan aman untuk dikonsumsi, serta mudah didapatkan oleh seluruh kalangan masyarakat (Zulkifli, 2017).

Pertumbuhan penduduk yang semakin meningkat khususnya di negara berkembang telah menjadikan berbagai penerapan teknologi dan inovasi pertanian untuk memenuhi kebutuhan pangan. Akan tetapi, penggunaan teknologi dan inovasi dalam kegiatan pertanian tersebut terkadang sering mengenyampingkan aspek lingkungan yang menyebabkan berkurangnya dan rusaknya sumber daya alam. Oleh karena itu, untuk mengatasi hal tersebut maka dibutuhkan ketahanan pangan yang ramah lingkungan yaitu dengan melalui pangan organik (Taufik, 2019).

Menurut Peraturan Menteri Pertanian No 64/Permentan/OT.140/5/2013 tentang Sistem Pertanian Organik Pasal 1 Ayat 3, pangan organik adalah pangan yang berasal dari suatu lahan pertanian organik yang menerapkan praktek pengelolaan yang bertujuan untuk memelihara ekosistem dalam mencapai produktivitas yang berkelanjutan, melakukan pengendalian gulma, hama, dan penyakit, melalui beberapa cara seperti daur ulang sisa tumbuhan dan ternak, seleksi dan pergiliran tanaman, pengelolaan air, pengolahan lahan, dan penanaman serta penggunaan bahan hayati (pangan). Salah satu produk dari pangan organik adalah padi organik.

Padi merupakan tanaman pangan yang menghasilkan beras sebagai bahan pangan pokok bagi masyarakat Indonesia. Salah satu kelebihan dari usahatani beras organik yaitu dapat meningkatkan pendapatan petani. Hal tersebut dikarenakan harga beras organik lebih mahal dibandingkan dengan harga beras pada umumnya. Sehingga hal tersebut memicu petani untuk mengembangkan beras organik (Suhardianto at al, 2007). Berdasarkan data statistik yang diperoleh dari FiBL ( Forschungsinstitut for Biologischen Lanbau) (2017) mengenai tren pertanian organik dunia, tercatat bahwa luas areal produksi padi organik di Indonesia pada tahun 2014-2016 mengalami peningkatan. Meskipun dari tahun 2015-2016 mengalami 
pengurangan, akan tetapi penurunan tersebut tidak telalu jauh. Hal ini dapat dikatakan bahwa perkembangan produksi padi organik cukup baik.

Tabel 1. Luas Areal Produksi Padi Organik Di Indonesia Tahun 2014-2016

\begin{tabular}{ccc}
\hline No & Tahun & Luas Lahan $(\mathrm{Ha})$ \\
\hline 1 & 2014 & 113.638 \\
2 & 2015 & 130.384 \\
3 & 2016 & 126.014 \\
\hline
\end{tabular}

Sumber : FiBL-IFOAM, 2017

Berkembangnya produksi padi organik di Indonesia disebabkan karena adanya pengaruh dari gaya hidup masyarakat Indonesia yang mulai memperhatikan pentingnya kesehatan dan lingkungan hidup, sehingga kebanyakan masyarakat Indonesia yang lebih memilih untuk mengkonsumsi produk organik dibandingkan dengan produk non-organik khususnya beras organik. Dengan adanya perubahan gaya hidup tersebut akan mendorong peningkatan permintaan terhadap produk organik, sehingga akan menyebabkan berkembangnya bisnis produk organik terutama beras organik (Irawati, 2011). Hal ini tentunya akan menguntungkan bagi pelaku usaha atau kelompok tani.

Salah satu pelaku usaha atau kelompok tani yang mengembangkan bisnis beras organik adalah Gapoktan Simpatik. Gapoktan Simpatik merupakan satu-satunya Gapoktan yang menghimpun petani padi organik yang ada di Tasikmalaya. Tahun 2008, Gapoktan berhasil menjalin kerjasama pemasaran dengan salah satu perusahaan sosial yang bergerak di bidang pertanian yaitu PT Bloom Agro yang berpusat di Jakarta. Berkat dukungan dari pemerintah dan PT Bloom Agro, anggota Gapoktan Simpatik berhasil memperoleh sertifikasi internasional dari Institute for Marketecology Organic (IMO) yang berbasis di Swiss. Akan tetapi, sertifikasi tersebut tidak semua anggota Gapoktan Simpatik mendapatkannya, hanya beberapa anggota saja (Dinas Pertanian Tanaman Pangan Kabupaten Tasikmalaya).

Melalui PT Bloom Agro dan dibawah merek dagang sunria, Gapoktan Simpatik berhasil melakukan ekspor perdana beras organik ke Amerika Serikat pada tahun 2009. Total ekspor beras yang telah dilakukan oleh Gapoktan Simpatik Tasikmalaya hingga tahun 2015 yaitu sebanyak 571 ton, dengan tujuan negara ekspor yaitu Amerika Serikat, Malaysia, Jerman, Singapura, UEA, Belanda, dan Italia. (Dinas Pertanian Tanaman Pangan Kabupaten Tasikmalaya). Tahun 2015, Gapoktan Simpatik Tasikmalaya berhasil bekerjasama dengan SOGO dan Rans Market untuk pemasaran beras organik di pasar lokal. Hingga saat ini, pangsa pasar beras organik di Gapoktan Simpatik Tasikmalaya yaitu 80\% pasar ekspor, dan $20 \%$ pasar lokal.

Kegiatan pemasaran beras organik di Gapoktan Simpatik Tasikmalaya cenderung mengalami penurunan dari tahun 2014. Meskipun pada tahun 2015 dan 2017 mengalami peningkatan penjualan, akan tetapi peningkatan tersebut masih dalam jumlah yang kecil (Tabel 2). Penurunan kegiatan penjualan tersebut akan mempengaruhi terhadap penerimaan Gapoktan Simpatik Tasikmalaya, terutama bagi para petani mitra. Selain itu dengan munculnya gapoktan ataupun produsen baru yang mengembangkan beras organik, menjadi hambatan bagi Gapoktan Simpatik dalam mempertahankan dan memperluas pasar. Meningkatnya persaingan tersebut, menjadi salah satu faktor yang membuat penjualan Gapoktan Simpatik menurun. Oleh karena itu, untuk meningkatkan daya saing dalam rangka mempertahankan dan memperluas pasar diperlukan suatu strategi pemasaran yang tepat. Berdasarkan uraian 
diatas, maka pada penulisan penelitian ini akan dibahas mengenai perumusan strategi pemasaran beras organik di Gapoktan Simpatik Tasikmalaya dengan melalui analisis faktor lingkungan perusahaan.

Tabel 2. Perkembangan Volume Penjualan Beras Organik Gapoktan Simpatik Tasikmalaya Tahun $2009-2017$

\begin{tabular}{ccc}
\hline No & Tahun & Volume Penjualan $(\mathrm{Kg})$ \\
\hline 1 & 2009 & 18.000 \\
2 & 2010 & 41.825 \\
3 & 2011 & 64.315 \\
4 & 2012 & 166.895 \\
5 & 2013 & 183.665 \\
6 & 2014 & 121.575 \\
7 & 2015 & 151.336 \\
8 & 2016 & 63.600 \\
9 & 2017 & 77.653 \\
\hline
\end{tabular}

Sumber : Gapoktan Simpatik Tasikmalaya, 2019

\section{METODOLOGI PENELITIAN}

Penelitian dilaksanakan di Gapoktan Simpatik yang berada di Desa Mekarwangi, Kecamatan Cisayong, Kabupaten Tasikmalaya. Pemilihan lokasi penelitian didasarkan karena Tasikmalaya merupakan salah satu sentra beras organik yang telah memasarkan produknya ke berbagai negara berkat adanya Gapoktan Simpatik. Meskipun Gapoktan Simpatik telah mampu memasarkan produknya ke berbagai negara, namun penjualannya masih belum bisa dikatakan maksimal. Hal ini disebabkan karena semenjak tahun 2014 Gapoktan Simpatik cenderung mengalami penurunan. Rendahnya kinerja tenaga kerja dan adanya produsen baru beras organik dianggap menjadi hambatan dalam proses pengembangan dan perluasan pasar. Penelitian dilaksanakan pada bulan Desember 2019 - Januari 2020.

Desain penelitian yang digunakan adalah desain penelitian deskriptif dengan metode kualitatif dan kuantitatif. Metode kualitatif digunakan untuk mendeskripsikan dan mengidentifikasi faktor-faktor lingkungan internal dan eksternal Gapoktan Simpatik. Sedangkan metode kuantitatif digunakan untuk merumuskan alternatif dan prioritas strategi pemasaran beras organik di Gapoktan Simpatik.

Metode pengolahan dan analisis data yang digunakan dalam penelitian ini yaitu dengan menganalisis lingkungan internal dan eksternal pemasaran dengan menggunakan formulasi strategi pemasaran. Menurut David (2009) formulasi strategi pemasaran terdiri dari tiga tahapan yaitu tahap input atau pembobotan, pemaduan dan pengambilan keputusan.

Tahap pemasukan (The Input Stage) digunakan matriks IFE (Internal Factor Evaluation) dan EFE (External Factor Evaluation). Menurut David (2009), matriks IFE (Internal Faktor Evaluation) merupakan alat untuk menganalisis faktor-faktor internal perusahaan yang digunakan dalam perumusan strategi untuk mengidentifikasi dan mengevaluasi kekuatan dan kelemahan utama dalam berbagai bidang fungsional dalam suatu usaha, serta menjadi landasan dalam mengidentifikasi dan mengevaluasi hubungan diantara bidang-bidang. Sedangkan matriks EFE ( External Faktor Evaluation ) merupakan alat untuk menganalisis 
faktor-faktor eksternal perusahaan yang digunakan dalam perencanaan strategi untuk mengidentifikasi dan mengevaluasi berbagai informasi ekonomi, sosial, budaya, demografi, lingkungan, politik, pemerintah, hukum, teknologi dan persaingan yang kemudian diklasifikasikan menjadi peluang dan ancaman bagi perusahaan.

Tahap pemaduan (The Matching Stage) digunakan alat analisis Matriks IE (untuk menentukan posisi usaha) dan Matriks SWOT (untuk memperoleh alternatif strategi). Menurut David (2009), matriks IE memposisikan berbagai divisi suatu organisasi dalam tampilan sembilan sel seperti yang ditunjukkan pada Gambar berikut:

\begin{tabular}{c|c|c|c|}
\multicolumn{1}{c}{ Tinggi $3.0-4.0$} & Kuat $3.0-4.0$ & Rata-rata 2.0-2.9 & Lemah $1.0-1.99$ \\
\cline { 2 - 4 } & I & II & III \\
\cline { 2 - 4 } Menengah 2.0 -2.99 & IV & V I \\
\cline { 2 - 4 } Rendah $1.0-1.99$ & VII & VIII & IX \\
\cline { 2 - 4 } & & & \\
\hline
\end{tabular}

Sumber : David, 2009

Matriks IE diatas dikelompokkan menjadi tiga bagian besar yang mempunyai implikasi strategi yang berbeda-beda :

1. Grow and build strategies (tumbuh dan membangun) Bagian ini terletak pada sel I, II, atau IV. Strategi yang bisa diterapkan pada bagian ini yaitu strategi intensif (penetrasi pasar, perkembangan pasar, perkembangan produk) dan strategi integrasi (integrasi ke belakang, integrasi ke depan, dan integrasi horisontal).

2. Hold and maintain strategies (menjaga dan mempertahankan) Bagian ini terletak pada sel III, V, atau VII. Strategi yang bisa diterapkan pada bagian ini yaitu penetrasi pasar dan perkembangan produk.

3. Harvest or divest strategies (mengambil hasil atau melepaskan) Bagian ini terletak pada sel VI, VIII, atau IX. Pada bagian ini strategi yang bisa diterapkan yaitu memperkecil atau menutup usaha yang dilakukan perusahaan. Matriks SWOT merupakan alat untuk menyusun strategi pemasaran perusahaan dengan memadukan atau menyesuaikan antara kekuatan dan kelemahan yang dimiliki perusahaan dengan peluang dan ancaman eksternal yang akan dihadapi oleh perusahaan. Matriks SWOT diperoleh dari hasil analisis identifikasi matriks IFE dan EFE.

Matriks SWOT merupakan alat untuk menyusun strategi pemasaran perusahaan dengan memadukan atau menyesuaikan antara kekuatan dan kelemahan yang dimiliki perusahaan dengan peluang dan ancaman eksternal yang akan dihadapi oleh perusahaan. Matriks SWOT diperoleh dari hasil analisis identifikasi matriks IFE dan EFE. 


\begin{tabular}{|c|c|c|}
\hline Faktor Internal & $\begin{array}{l}\text { Strength }(\mathrm{S}) \text { Faktor } \\
\text { Kekuatan }\end{array}$ & $\begin{array}{c}\text { Weakness (W) Faktor } \\
\text { Kelemahan }\end{array}$ \\
\hline $\begin{array}{c}\text { Opportunities }(\mathrm{O}) \text { Faktor } \\
\text { Peluang }\end{array}$ & $\begin{array}{c}\text { Strategi SO } \\
\text { Strategi yang menggunakan } \\
\text { kekuatan untuk } \\
\text { memanfaatkan peluang } \\
\text { eksternal perusahaan }\end{array}$ & $\begin{array}{c}\text { Strategi WO } \\
\text { Strategi yang } \\
\text { meminimumkan kelemahan } \\
\text { untuk memanfaatkan peluag } \\
\text { eksternal }\end{array}$ \\
\hline $\begin{array}{c}\text { Threaths }(\mathrm{T}) \text { Faktor } \\
\text { Ancaman }\end{array}$ & $\begin{array}{c}\text { Strategi ST } \\
\text { Stretegi yang menggunakan } \\
\text { kekuatan internet untuk } \\
\text { mengatasi ancaman } \\
\text { eksternal perusahaan }\end{array}$ & $\begin{array}{c}\text { Strategi WT } \\
\text { Strategi yang } \\
\text { meminimumkan kelemahan } \\
\text { dan menghindari ancaman }\end{array}$ \\
\hline
\end{tabular}

Gambar 2. Matriks SWOT

Tahap terakhir adalah tahap pengambilan keputusan (The Decision Stage) dengan menggunakan Matriks QSPM. Menurut David (2009), Quantitative Strategic Planning Matrix (QSPM) merupakan alat yang memungkinkan para penyusun strategi untuk mengevaluasi berbagai alternatif strategi yang telah diidentifikasi sebelumnya. Tujuan dari analisis ini yaitu untuk memperoleh prioritas strategi bagi perusahaan. Matriks QSPM ini diperoleh dengan melalui perpaduan antara matriks SWOT dengan matriks IE.

\section{HASIL DAN PEMBAHASAN}

Faktor Internal dan Eksternal Faktor-faktor strategis internal dan eksternal didapat dari hasil wawancara dengan beberapa informan mengenai faktor-faktor yang berhubungan dengan lingkungan internal Gapoktan Simpatik seperti faktor operasional, faktor sumber daya manusia, faktor pemasaran (produk, harga, tempat dan promosi), dan faktor keuangan, serta faktor-faktor yang berhubungan dengan lingkungan eksternal Gapoktan Simpatik seperti faktor politik, hukum dan pemerintah, faktor teknologi, faktor sosial budaya dan lingkungan, serta faktor pesaing. Berdasarkan hasil wawancara tersebut kemudian dapat diketahui mengenai kekuatan, kelemahan, peluang dan ancaman bagi Gapoktan Simpatik seperti yang dijelaskan pada Tabel 3 dan 4.

\section{Matriks Internal Factor Evaluation (IFE)}

Berdasarkan hasil dari perhitungan matriks IFE, yang menjadi kekuatan utama beras organik Gapoktan Simpatik adalah jenis produk beras organik yang ditawarkan beragam dan kualitas beras yang premium dengan total nilai 0.284 dan 0.200. Sedangkan yang menjadi kelemahan utama bagi Gapoktan Simpatik yaitu Sumber Daya Manusia yang sedikit dengan total nilai 0.142. Hal ini tentunya akan mempengaruhi terhadap jalannya kegiatan di Gapoktan Simpatik. 
Tabel 3. Kekuatan dan Kelemahan Gapoktan Simpatik

\begin{tabular}{llll}
\hline \multicolumn{3}{c}{ FAKTOR-FAKTOR STRATEGIS INTERNAL } \\
\hline \multicolumn{1}{c}{ Kekuatan } & \multicolumn{1}{c}{ Kelemahan } \\
\hline 1 & Kualitas Produk Premium & 1 & Kinerja Tenaga Kerja Rendah. \\
2 & Jenis Produk Yang Ditawarkan & 2 & Sumber Daya Manusia Sedikit. \\
& Beragam & 3 & Sumber Keuangan Lemah. \\
3 & Harga yang Kompetitif dan & 4 & Kurangnya Pangsa Pasar. \\
& Terjangkau. & 5 & Teknologi Alat Produksi Belum \\
4 & Ketepatan Waktu Dalam & & Canggih. \\
& Pendistribusian. & 6 & Kegiatan Promosi Lemah \\
5 & Keamanan Makanan Terjamin & & \\
6 & Kemasan Simpel dan Menarik. & & \\
7 & Fasilitas Produksi Lengkap. & & \\
8 & Kemampuan Bermitra. & & \\
9 & Memiliki Legalitas dan Sertifikasi & & \\
& (Nasional dan Internasional) & & \\
\hline
\end{tabular}

Tabel 4. Peluang dan Ancaman Bagi Gapoktan Simpatik

\begin{tabular}{llll}
\hline \multicolumn{3}{c}{ FAKTOR-FAKTOR STRATEGIS EKSTERNAL } \\
\hline \multicolumn{1}{c}{ Peluang } & \multicolumn{1}{c}{ Ancaman } \\
\hline 1 & Meningkatnya kesadaran masyarakat & 1 & Meningkatnya persaingan bisnis beras \\
& terhadap pola hidup sehat. & 2 & organik (Nasional dan Internasional). \\
2 & Pasar Global. & 3 & Dukungan pemerintah berkurang. \\
3 & Perkembangan teknologi informasi dan & 4 & Kebijakan perdagangan dan pajak \\
& digital marketing. & & ekspor. \\
4 & Peningkatan jumlah produksi. & \\
\end{tabular}

\section{Matriks Eksternal Factor Evaluation (EFE)}

Berdasarkan hasil perhitungan matriks EFE, terdapat tiga peluang yang sangat mendukung terhadap peningkatan bisnis organik. Tiga peluang tersebut yaitu meningkatnya kesadaran masyarakat terhadap pola hidup sehat, perkembangan teknologi informasi dan digital marketing, dan pasar global dengan total nilai 0,444. Sedangkan yang menjadi ancaman utama tersebut yaitu meningkatnya persaingan bisnis beras organik di pasar domestik dan internasional dengan total nilai 0,222 . 
Tabel 5. Penghitungan Matriks IFE Gapoktan Simpatik

\begin{tabular}{|c|c|c|c|c|}
\hline No & Faktor-Faktor Strategis Internal & Bobot & Rating & Bobot x Rating \\
\hline \multicolumn{5}{|c|}{ Kekuatan } \\
\hline 1 & Kualitas Produk Premium & 0,050 & 4 & 0,200 \\
\hline 2 & Jenis Produk yang Ditawarkan & 0.071 & 4 & 0,284 \\
\hline \multirow[t]{2}{*}{3} & Harga yang Kompetitif dan & & & \\
\hline & Terjangkau & 0,048 & 3 & 0,144 \\
\hline \multirow[t]{2}{*}{4} & Ketepatan Waktu dalam & & & \\
\hline & Pendistribusian & 0,048 & 3 & 0,144 \\
\hline 5 & Keamanan Makanan Terjamin & 0,048 & 4 & 0,192 \\
\hline 6 & Kemasan Simpel dan Menarik & 0,070 & 2 & 0,140 \\
\hline 7 & Fasilitas Produksi Lengkap & 0,048 & 3 & 0,144 \\
\hline 8 & Kemampuan Bermitra & 0,048 & 4 & 0,192 \\
\hline \multirow[t]{2}{*}{9} & Memiliki Legalitas dan & & & \\
\hline & Sertifikasi & 0,048 & 4 & 0,192 \\
\hline \multicolumn{5}{|c|}{ Kelemahan } \\
\hline 1 & Kinerja Tenaga Kerja Rendah & 0,100 & 2 & 0,200 \\
\hline 2 & Sumber Daya Manusia Sedikit & 0,071 & 2 & 0,142 \\
\hline 3 & Sumber Keuangan Lemah & 0,090 & 2 & 0,180 \\
\hline 4 & Kurangnya Pangsa Pasar & 0,095 & 2 & 0,190 \\
\hline 5 & $\begin{array}{l}\text { Teknologi Alat Produksi Belum } \\
\text { Canggih }\end{array}$ & 0,081 & 2 & 0,162 \\
\hline \multirow[t]{2}{*}{6} & Kurang Kegiatan Promosi & 0,086 & 3 & 0,258 \\
\hline & Total & 1 & & 2,764 \\
\hline
\end{tabular}

Tabel 6. Penghitungan Matriks EFE Gapoktan Simpatik

\begin{tabular}{llccc}
\hline No & Faktor-Faktor Strategis Internal & Bobot & Rating & Bobot x Rating \\
\hline \multicolumn{1}{c}{ Peluang } & & & \\
\hline 1 & $\begin{array}{l}\text { Meningkatnya Kesadaran } \\
2\end{array}$ & 0,111 & 4 & 0.444 \\
$\begin{array}{l}\text { Masyarakat Terhadap Pola } \\
\text { Hidup Sehat }\end{array}$ & 0,111 & 4 & 0.444 \\
$\begin{array}{l}\text { Perkembangan Teknologi } \\
\text { Informasi dan Digital Marketing } \\
\text { Peningkatan Jumlah Produksi }\end{array}$ & 0,111 & 3 & 0,333 \\
& \multicolumn{1}{c}{ Pasar Global Ancaman } & 4 & 0.444 \\
\hline 1 & $\begin{array}{l}\text { Meningkatnya Persaingan } \\
\text { Bisnis Beras Organik (nasional } \\
\text { dan internasional) }\end{array}$ & 0,222 & 1 & 0,222 \\
$\begin{array}{l}\text { Dukungan Pemerintah } \\
\text { Berkurang }\end{array}$ & $\begin{array}{l}\text { Kebijakan Perdagangan dan } \\
\text { Pajak Ekspor }\end{array}$ & 0,198 & 2 & 0,396 \\
\hline Total & 0,173 & 2 & 0,346 \\
\hline
\end{tabular}




\section{Matriks Internal-Eksternal (IE)}

Matriks IE diperoleh dari total skor yang dihasilkan dari matriks IFE (sumbu X) dan matriks EFE (sumbu Y). Masing-masing total skor yang dihasilkan dari matriks IFE dan EFE adalah 2.764 dan 2.629 yang menunjukan posisi internal Gapoktan Simpatik rata-rata dan posisi eksternal menengah. Sehingga hasil dari matriks IE menunjukkan bahwa Gapoktan Simpatik berada pada posisi sel V. Artinya strategi yang dapat digunakan oleh Gapoktan Simpatik adalah Hold and Mantains (pertahankan dan pelihara) dengan melakukan strategi penetrasi pasar dan perkembangan produk.

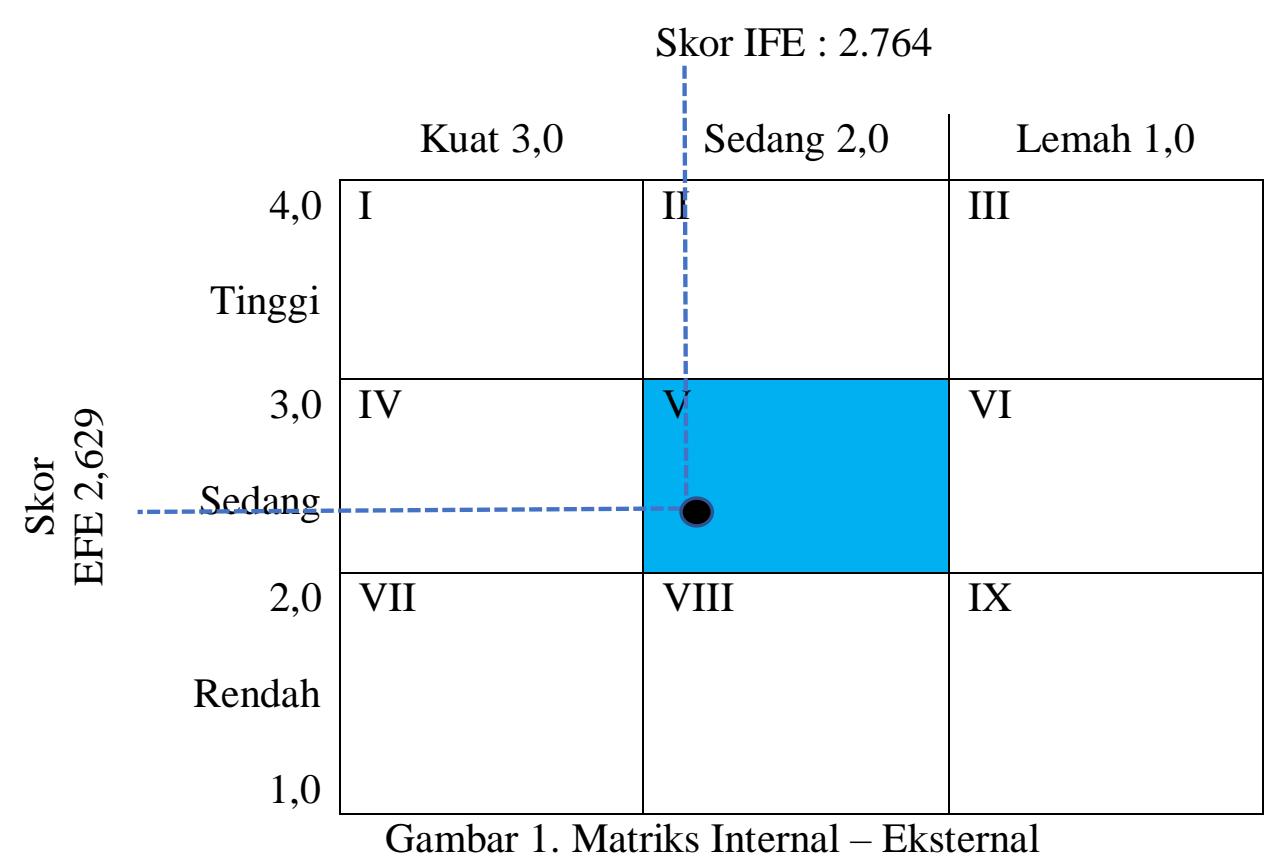

\section{Matriks SWOT}

Alternatif strategi yang akan direkomendasikan ke Gapoktan Simpatik akan dirumuskan dengan menggunakan matriks SWOT yang nantinya akan digunakan di analisis QSPM. Matriks SWOT ini dihasilkan dari analisis identifikasi matriks IFE dan EFE. Matriks SWOT akan menghasilkan empat sel yang kemungkinan dapat digunakan sebagai alternatif strategi. Keempat sel tersebut diantaranya yaitu strategi SO, strategi ST, strategi WO, strategi WT. Hasil analisis matriks SWOT dapat dijelaskan sebagai berikut:

1. Berdasarkan strategi SO yaitu strategi yang mengoptimalkan kekuatan untuk memanfaatkan peluang sebanyak-banyaknya.

- Meningkatkan kerjasama dengan berbagai mitra pemasaran yang terkait untuk menjangkau dan memperluas pasar.

- Mempertahankan kelengkapan fasilitas produksi untuk meningkatkan jumlah produksi

2. Berdasarkan strategi ST yaitu strategi yang memanfaatkan kekuatan untuk mengatasi ancaman.

- Mempertahankan kualitas, kemasan, Harga, jenis dan keamanan dalam rangka 
meningkatkan daya saing.

- Meningkatkan kerjasama dengan pemerintah dalam mengembangkan bisnis beras organik.

3. Berdasarkan strategi WO yaitu strategi yang meminimalkan kelemahan dengan memanfaakan peluang yang ada.

- Meningkatkan jumlah dan kinerja tenaga kerja serta modal dalam rangka meningkatkan jumlah produksi.

- Memanfaatkan perkembangan teknologi informasi dan digital marketing dengan optimal untuk meningkatkan pangsa pasar dan kegiatan promosi.

4. Berdasarkan strategi WT yaitu strategi yang meminimalkan kelemahan dan menghindari ancaman.

- Meningkatkan jumlah dan kinerja tenaga kerja serta modal dalam meningkatkan daya saing.

\begin{tabular}{|c|c|c|}
\hline Faktor Eksternal & $\begin{array}{l}\text { Strength (S) } \\
\text { 1. Kualitas Produk Premium } \\
\text { 2. Jenis Produk yang Ditawarkan } \\
\text { Beragam } \\
\text { 3. Harga yang Kompetitif dan } \\
\text { Terjangkau } \\
\text { 4. Ketepatan Waktu Dalam } \\
\text { Pendistribusian } \\
\text { 5. Keamanan Makanan Terjamin } \\
\text { 6. Kemasan Simpel dan Menarik } \\
\text { 7. Fasilitas Produksi Lengkap } \\
\text { 8. Kemampuan Bermitra } \\
\text { 9. Memiliki Legalitas dan } \\
\text { Sertifikasi }\end{array}$ & $\begin{array}{l}\text { Weakness (W) } \\
\text { 1.Kinerja Tenaga Kerja Rendah } \\
\text { 2. Sumber Daya Manusia Sedikit } \\
\text { 3. Sumber Keuangan Lemah } \\
\text { 4. Kurangnya Pangsa Pasar } \\
\text { 5. Teknologi Alat Produksi Belum } \\
\text { Canggih } \\
\text { 6. Kurang Kegiatan Promosi }\end{array}$ \\
\hline $\begin{array}{l}\text { Opportunities }(\mathrm{O}) \\
\text { 1. Meningkatnya kesadaran } \\
\text { masyarakat terhadap pola hidup } \\
\text { sehat } \\
\text { 2. Perkembangan teknologi } \\
\text { informasi dan digital marketing } \\
\text { 3. Peningkatan jumlah produksi } \\
\text { 4. Pasar Global }\end{array}$ & $\begin{array}{l}\text { Strategi S-O } \\
\text { 1. Meningkatkan kerjasama } \\
\text { dengan berbagai mitra } \\
\text { pemasaran yang terkait untuk } \\
\text { menjangkau dan memperluas } \\
\text { pasar (S1, S2, S3, S4, S5, S6, } \\
\text { S7, S8, S9, O1, O3, O4) } \\
\text { 2. Mempertahankan kelengkapan } \\
\text { fasilitas produksi untuk } \\
\text { meningkatkan jumlah produksi } \\
\text { (S7, O1, O2, O3) }\end{array}$ & $\begin{array}{l}\text { Strategi W-O } \\
\text { 1. Meningkatkan jumlah dan } \\
\text { kinerja tenaga kerja serta modal } \\
\text { dalam rangka meningkatkan } \\
\text { jumlah produksi (W1, W2, W3, } \\
\text { W5, O3, O4) } \\
\text { 2. Memanfaatkan perkembangan } \\
\text { teknologi informasi dan digital } \\
\text { marketing untuk meningkatkan } \\
\text { pangsa pasar dan kegiatan } \\
\text { promosi (W4, W6, O1, O2, O4) }\end{array}$ \\
\hline $\begin{array}{l}\text { Threaths }(\mathrm{T}) \\
\text { 1. Meningkatnya persaingan } \\
\text { bisnis beras organik (Nasional } \\
\text { dan Internasional) } \\
\text { 2. Dukungan pemerintah } \\
\text { berkurang } \\
\text { 3. Kebijakan perdagangan dan } \\
\text { pajak ekspor }\end{array}$ & $\begin{array}{l}\text { Strategi S-T } \\
\text { 1. Mempertahankan kualitas, } \\
\text { kemasan, Harga, jenis dan } \\
\text { keamanan dalam rangka } \\
\text { meningkatkan daya saing (S1, } \\
\text { S2, S3, S5, S6, S8, T1, T2) } \\
\text { 2. Meningkatkan kerjasama } \\
\text { dengan pemerintah dalam } \\
\text { mengembangkan bisnis beras } \\
\text { organik (S1, S2, S3, S5, S8, } \\
\text { S9, T1, T2) }\end{array}$ & $\begin{array}{l}\text { Strategi W-T } \\
\text { Meningkatkan jumlah dan } \\
\text { kinerja tenaga kerja serta modal } \\
\text { dalam meningkatkan daya saing } \\
\text { (W1, W2, W3, W4, W5, T1, } \\
\text { T2) }\end{array}$ \\
\hline
\end{tabular}

Gambar 4. Matriks SWOT Gapoktan Simpatik 


\section{Matriks QSPM}

Berdasarkan hasil perhitungan Total Attractive Score (TAS), alternative strategi yang paling menarik dan diprioritaskan untuk diimplementasikan oleh Gapoktan Simpatik dalam meningkatkan daya saing dan perluasan pasar yaitu meningkatkan 11erjasama dengan berbagai mitra pemasaran yang terkait untuk menjangkau dan memperluas pasar serta memanfaatkan perkembangan teknologi informasi dan digital marketing secara optimal dalam meningkatkan pangsa pasar dan kegiatan promosi.

Tabel 7. Prioritas Strategi Pengembangan Bisnis Padi Organik

\begin{tabular}{|c|l|c|}
\hline No & \multicolumn{1}{|c|}{ Prioritas Strategi } & Total Skor \\
\hline 1 & $\begin{array}{l}\text { Meningkatkan kerjasama dengan berbagai mitra } \\
\text { pemasaran yang terkait untuk menjangkau dan } \\
\text { memperluas pasar. }\end{array}$ & $\begin{array}{l}\text { Memanfaatkan perkembangan teknologi informasi dan } \\
\text { digital marketing dengan optimal untuk meningkatkan } \\
\text { pangsa pasar dan kegiatan promosi. }\end{array}$ \\
3 & $\begin{array}{l}\text { Meningkatkan kerjasama dengan pemerintah dalam } \\
\text { mengembangkan bisnis beras organic. }\end{array}$ & 7,244 \\
5 & $\begin{array}{l}\text { Mempertahankan kualitas, kemasan, Harga, jenis dan } \\
\text { keamanan dalam rangka meningkatkan daya saing. } \\
\text { meningkatkan jumlah dan kinerja tenaga kerja serta } \\
6\end{array}$ & $\begin{array}{l}\text { Meningkatkan jumlah dan kinerja tenaga kerja serta } \\
\text { modal dalam rangka meningkatkan jumlah produksi. } \\
7\end{array}$ \\
\hline $\begin{array}{l}\text { Mempertahankan kelengkapan fasilitas produksi untuk } \\
\text { meningkatkan jumlah produksi. }\end{array}$ & 6,936 \\
\hline
\end{tabular}




\section{SIMPULAN DAN SARAN}

\section{Simpulan}

Beberapa hal yang dapat disimpulkan dari penelitian ini adalah:

1. Berdasarkan kondisi lingkungan internal, yang menjadi kekuatan utama beras organik Gapoktan Simpatik adalah jenis produk beras organik yang ditawarkan beragam dan memiliki kualitas beras premium. Sedangkan untuk kelemahan utamanya adalah sumber daya manusia yang sedikit. Berdasarkan kondisi lingkungan eksternal, yang paling mempengaruhi dalam perkembangan bisnis beras organik yaitu meningkatnya persaingan bisnis beras organik di pasar domestik dan internasional menjadi ancaman utama bagi Gapoktan Simpatik. Sedangkan peluang bagi Gapoktan Simpatik yaitu meningkatnya kesadaran masyarakat terhadap pola hidup sehat, meningkatnya teknologi informasi dan digital marketing serta pasar global.

2. Berdasarkan hasil dari matriks IE diketahui bahwa Gapoktan Simpatik berada pada kelompok usaha hold and maintain strategy (strategi mempertahankan dan memelihara). Sehingga, strategi yang dapat dilakukan yaitu penetrasi pasar dan pengembangan produk. Dengan demikian diperoleh tujuh strategi aplikatif dari strategi penetrasi pasar dan pengembangan produk yang dihasilkan dari matriks SWOT. Sedangkan dari hasil matriks QSPM diperoleh strategi prioritas yaitu meningkatkan kerjasama dengan berbagai mitra pemasaran yang terkait untuk menjangkau dan memperluas pasar.

\section{Saran}

Saran yang dapat diajukan dalam penelitian ini adalah:

1. Mengevaluasi perjanjian kerjasama dengan mitra pemasaran, khususnya PT. Bloom Agro terkait volume permintaan.

2. Mengoptimalkan penggunaan sosial media dan digital marketing dalam memperluas jangkauan pasar seperti penggunaan website, e-commerce dan teknologi lainnya yang berhubungan dengan pemasaran.

3. Mempertahankan strategi yang telah ada dan mengimplementasikan strategi yang telah disusun dan diprioritaskan dalam penelitian ini dengan disertai perencanaan dan pertimbangan yang matang serta disesuaikan dengan visi dan misi dari Gapoktan Simpatik untuk meningkatkan daya saing dan memperluas pasar.

\section{DAFTAR PUSTAKA}

Ahyani, MY. 2009. Strategi Pemasaran Ekspor Buah-Buahan Pada PT. Agroindo Usaha Jaya. Skripsi. Institut Pertanian Bogor (IPB). Bogor.

Aliyah, Zulfa. 2018. Analisis Strategi Pemasaran Dalam Meningkatkan Penjualan Ekspor Kopi Arabika Pada CV Yudi Putra. Skripsi. Universitas Islam Negeri Sumatera Utara. Medan.

Anggraini RDP, Rondhi M, Wibowo R. 2018. Analisis Pemasaran Beras Organik Di Kabupaten Bondowoso (Market Analysis Of Organic Rice In Bondowoso). Journal Ekonomi Pertanian dan Agribisnis (JEPA). 5(18): 417-425. 
Assauri, Sofyan. Manajemen Pemasaran, Jakarta: Rajawali Pers, 2013. Biocert. 2008. Potret Perkembangan Pertanian Organik Asia. Newsletter Trust in Organic Edisi 9/Th.2 (Januari - Maret 2008).

Dasipah E, Nursinah Z, Taryadi. 2013. Marketing Analysis Strategy Organic Rice At UD. Padi Marketing Region Bekasi. International Journal Of Nusantara Islam. 1(2): 22525904. David, Fred R. 2009. Strategic Management, Concept \& Cases. Prentice Hall. New Jersey (US). David, Fred R. 2004. Manajemen Strategis Konsep. Edisi Kesembilan. Prentice Hall. Indeks. Jakarta.

[Distan] Dinas Pertanian Tanaman Pangan Kabupaten Tasikmalaya. 2009. Komoditas Padi Organik. Dinas Pertanian Kabupaten Tasikmalaya. Tasikmalaya.

Elizabeth, Ayu. 2019. Manajemen Pemasaran Ekspor Manggis Di Tingkat Eksportir (Studi Kasus Di PT. Nusantara Segar Global Sebagai Eksportir Manggis Di Kecamatan Puspahiang Kabupaten Tasikmalaya). Universitas Padjadjaran. Jatinangor.

Fajriyah LW. 2018. Strategi Pemasaran Dalam Meningkatkan Penjualan Tahubaxo Ibu Pudji Ungaran Dalam Perspektif Ekonomi Islam. Skripsi. Universitas Negeri Islam Walisongo. Semarang.

[IFOAM] International Federation of Organic Agriculture Movements. 2011. "Principles of Organic Agriculture". [Diakses pada tanggal Oktober 2019]. Tersedia pada: http://www.ifoam.org.

Kasymir DA. 2018. Strategi Pemasaran PT Sayuran Siap Saji Kabupaten Bogor Jawa Barat. Skripsi. Universitas Lampung. Bandar Lampung.

Krystallis A, G Chryssohoidis. 2010. Consumers' willingness to pay for organic food: Factors that affect it and variation per organic product type. British Food Journal. 107(5): 320- 343.

Kohls RL, Uhl JN. 1990. Marketing of Agricultural Products. Ninth Edition. McMillan Publishing Company. New York.

Kotler P dan Amstrong G. 1995. Dasar-dasar Pemasaran. Intermedia. Jakarta Kotler P. 2002. Manajemen Pemasaran. Edisi Millenium Jilid 1. PT Prehallindo. Jakarta.

Mayrowani H. 2012. Pengembangan Pertanian Organik di Indonesia. Skripsi. Institut Pertanian Bogor (IPB). Bogor.

[Menper] Menteri Pertanian. 2013. Peraturan Menteri Pertanian Nomor 64/Permentan/OT.140/5/2013. Menteri Pertanian. Jakarta.

Nafis, Faisal. 2011. Analisis Usahatani Padi Organik Dan Sistem Tataniaga Beras Organik Di Kabupaten Tasikmalaya Provinsi Jawa Barat. Skripsi. Institut Pertanian Bogor (IPB). Bogor.

Pearce JA, Robinson. 2008. Manajemen Strategik: Formulasi, Implementasi dan Pengendalian, Jilid I. Bina Rupa Aksara. Jakarta. 
Purnama, DF. 2009. Strategi Pemasaran Produk Olahan Wortel (Studi Kasus Kelompok Wanita Tani Kartini Di Kawasan Rintisan Agropolitan Kecamatan Cipanas Kabupaten Cianjur). Skripsi. Institut Pertanian Bogor (IPB). Bogor.

Rangkuti, Freddy. Strategi Promosi yang Kreatif dan Analisis Kasus Integrated Marketing Communication. Gramedia Pustaka. Jakarta.

Seminar KB, Sutrisno, Sugiyanta, Purwandoko PB. 2018. Analisis Rantai Pasok Beras Organik di Provinsi Jawa Barat. Artikel. Institut Pertanian Bogor (IPB). Bogor.

Simbolon, HB. 2003. Peranan Pertanian Organik dalam Pertanian Berkelanjutan dan Peluang Penerapannya di Indonesia. Institut Pertanian Bogor (IPB). Bogor.

Sutanto R. 2002. Pertanian Organik: Menuju Pertanian Alternatif dan Berkelanjutan. Yogyakarta.

Tamburian, Effatha GVG. (2018, 13 Juli). Ini Wujud Pesan Bung Karno Soal Ketahanan Bangsa. Diakses Oktober 2019, dari https://www.gesuri.id/kerakyatan/ini-wujudpesan-bung-karno-soal-ketahanan-pangan-bangsa-b1T2wZdcI.

Tjiptono, Fandy. 2004. Manajemen Pemasaran. CV Andi Offset. Yogyakarta.

Tjiptono, Fandy. 2002. Strategi Pemasaran. CV Andi Offset. Yogyakarta.

Willer H, Yussefi M, Sorensen. 2009. The World of Organic Agriculture: Statistics and Emerging Trends 2008. IFOAM and Research Institute of Organic Agriculture (FiBL). Bonn (DE).

Zulkifli, Lutfi. 2017. Strategi Pemasaran Padi Organik Pada Kelompok Tani Sri Makmur Di Kabupaten Sragen. Skripsi. Institut Pertanian Bogor (IPB). Bogor. 